\title{
Cochrane
Library
}

Cochrane Database of Systematic Reviews

\section{Pegylated granulocyte colony stimulating factor versus non- pegylated granulocyte colony stimulating factor for peripheral stem cell mobilization (Protocol)}

Kuan JW, Su AT, Leong CF, Tharyan P

Kuan JW, Su AT, Leong CF, Tharyan P.

Pegylated granulocyte colony stimulating factor versus non-pegylated granulocyte colony stimulating factor for peripheral stem cell mobilization.

Cochrane Database of Systematic Reviews 2016, Issue 2. Art. No.: CD010103.

DOI: 10.1002/14651858.CD010103.pub2.

www.cochranelibrary.com

Pegylated granulocyte colony stimulating factor versus non-pegylated granulocyte colony stimulating factor for peripheral stem cell mobilization (Protocol)

Copyright $\odot 2016$ The Cochrane Collaboration. Published by John Wiley \& Sons, Ltd. 
TABLE OF CONTENTS

HEADER . . . . . . . . . . . . . . . . . . . . . . . . . . . . . . . . . . . . . . . 1

REASON FOR WITHDRAWAL . . . . . . . . . . . . . . . . . . . . . . . . . . . . . . . . . . . . . . . . . 1

WHAT'S NEW . . . . . . . . . . . . . . . . . . . . . . . . . . . . . . . . . . . . . . . . 1

SOURCES OF SUPPORT . . . . . . . . . . . . . . . . . . . . . . . . . . . . . . . . .

Pegylated granulocyte colony stimulating factor versus non-pegylated granulocyte colony stimulating factor for peripheral stem cell mobilization (Protocol)

Copyright $\odot 2016$ The Cochrane Collaboration. Published by John Wiley \& Sons, Ltd. 


\title{
[Intervention Protocol]
}

\section{Pegylated granulocyte colony stimulating factor versus non- pegylated granulocyte colony stimulating factor for peripheral stem cell mobilization}

\author{
Jew-Win Kuan ${ }^{1}$, Anselm Ting Su ${ }^{2}$, Chooi-Fun Leong ${ }^{3}$, Prathap Tharyan ${ }^{4}$ \\ ${ }^{1}$ Department of Medicine, Faculty of Medicine and Health Sciences, Universiti Malaysia Sarawak, Sarawak, Malaysia. ${ }^{2}$ Department of \\ Community Medicine and Public Health, Faculty of Medicine and Health Sciences, Universiti Malaysia Sarawak, Sarawak, Malaysia. \\ ${ }^{3}$ Department of Pathology, University Kebangsaan Malaysia Medical Center, Kuala Lumpur, Malaysia. ${ }^{4}$ Cochrane South Asia, Prof. \\ BV Moses Center for Evidence-Informed Health Care and Health Policy, Christian Medical College, Vellore, India \\ Contact address: Jew-Win Kuan, Department of Medicine, Faculty of Medicine and Health Sciences, Universiti Malaysia Sarawak, \\ 94300 Kota Samarahan, Sarawak, Malaysia. kuanjewwin@gmail.com.
}

Editorial group: Cochrane Haematological Malignancies Group.

Publication status and date: Withdrawn from publication for reasons stated in the review, published in Issue 2, 2016.

Citation: Kuan JW, Su AT, Leong CF, Tharyan P. Pegylated granulocyte colony stimulating factor versus non-pegylated granulocyte colony stimulating factor for peripheral stem cell mobilization. Cochrane Database of Systematic Reviews 2016, Issue 2. Art. No.: CD010103. DOI: 10.1002/14651858.CD010103.pub2.

Copyright (C) 2016 The Cochrane Collaboration. Published by John Wiley \& Sons, Ltd.

The editorial group responsible for this previously published document have withdrawn it from publication.

\section{REASON FOR WITHDRAWAL}

The completion of the last task is overdue for more than one year. New authors are being sought to take over this protocol.

\section{WHAT'S NEW}

Last assessed as up-to-date: 25 May 2015.

Date Event Description

4 February 2016 Amended withdrawn

Pegylated granulocyte colony stimulating factor versus non-pegylated granulocyte colony stimulating factor for peripheral stem cell 


\section{SOURCES OF SUPPORT}

\section{Internal sources}

- Julius Centre University of Malaya, Malaysia.

This work is part of the STeMM Programme supported by the University of Malaya/Ministry of Higher Education (UM/MOHE) High Impact Research Grant (Grant number E000010-20001). The scope of funding includes capacity building and training via Cochrane Systematic Reviews Workshop, Cochrane Completion Review Workshop, provision of the Cochrane Library database and support in retrieving full text articles.

\section{External sources}

- Clinical Research Center, Sarawak General Hospital, Malaysia.

It supported one of the authors, KJW, to attend "COCHRANE REVIEW COMPLETION WORKSHOP" organized by Julius Centre University of Malaya on 4-6th Mac 2014. 